\title{
Review
}

Journal of Innate

Immunity
$\mathrm{J}$ Innate Immun 2011;3:337-343

DOI: $\underline{10.1159 / 000328005}$
Received: November 1, 2010

Accepted after revision: March 31, 2011

Published online: May 11, 2011

\section{Immunosenescence of Human Natural Killer Cells}

\author{
Inmaculada Gayoso ${ }^{a}$ Beatriz Sanchez-Correab Carmen Campos ${ }^{a}$ \\ Corona Alonso $^{a}$ Alejandra Pera ${ }^{a}$ Javier G. Casado ${ }^{b}$ Sara Morgado ${ }^{b}$ \\ Raquel Tarazona $^{\mathrm{b}}$ Rafael Solana ${ }^{\mathrm{a}}$ \\ ${ }^{a}$ Department of Immunology, IMIBIC - Reina Sofia University Hospital, University of Cordoba, Cordoba, and \\ ${ }^{\mathrm{b}}$ Immunology Unit, Department of Physiology, University of Extremadura, Cáceres, Spain
}

\section{Key Words}

Aging $\cdot$ Immunosenescence $\cdot$ Natural killer cells, receptors . Cytokines

\begin{abstract}
Natural killer (NK) cells are a key component of innate immunity involved not only in the elimination of virus-infected or tumor cells but also in the regulation of the immune response by producing cytokines and chemokines that can activate other cellular components of innate and adaptive immunity. NK cell subsets are differentially affected by aging. Whereas CD56 ${ }^{\text {bright }}$ cells are decreased in healthy elderly individuals, the CD56 $6^{\mathrm{dim}}$ subset is expanded. The expression of CD57, a marker of highly differentiated NK cells, is increased in the elderly; this supports the notion that a remodeling process of NK cell subsets occurs in aging with a gradual decrease in more immature CD56 bright NK cells and an increase in highly differentiated CD56 dim CD57+ NK cells. This NK cell redistribution can explain many of the phenotypic and functional changes in NK cells associated with healthy aging such as decreased proliferation and the maintenance of CD16dependent cytotoxicity.

Copyright $\odot 2011$ S. Karger AG, Basel
\end{abstract}

\section{Introduction}

Scientific and clinical advances in the last century have led to a worldwide increase in life expectancy. This, combined with falling birth rates in most countries, has led to a striking increase in both the relative and the absolute numbers of persons over 65 years of age not only in economically developed countries but also in developing countries. This increase in life expectancy has led to a striking increase in the frequency of diseases associated with aging, including infections $[1,2]$, an increased incidence of cancer [3, 4], and an increase in neurodegenerative and cardiovascular diseases $[5,6]$. Many of these diseases are linked to age-associated deterioration of the immune system, a process termed immunosenescence.

Immunosenescence is defined as the state of age-associated dysregulation of the immune function demonstrated in diverse species, including humans, that contributes to morbidity and mortality due to the greater incidence or reactivation of infectious diseases, as well as possibly autoimmune phenomena and cancer [2,7-9]. The capacity of the immune system to cope with infec-

\section{KARGER}

Fax +4161306 1234

E-Mail karger@karger.ch

www.karger.com (c) 2011 S. Karger AG, Basel

1662-811X/11/0034-0337\$38.00/0

Accessible online at:

www.karger.com/jin
Dr. Rafael Solana

Department of Immunology, Faculty of Medicine

Reina Sofia University Hospital, University of Cordoba

ES-14004 Cordoba (Spain)

Tel. +34957 011 493, E-Mail rsolana@uco.es 
tious diseases is lower in the elderly than in the young, probably as a consequence of altered immune responses to pathogens [10], indicating that the ability to respond efficiently to pathogens is eroded by immunosenescence.

Although it has been generally accepted that some aspects of innate immunity are well preserved in aging [11], cumulative evidence in the last decade supports the notion that immunosenescence affects not only adaptive immunity but also innate immunity. Thus age-associated alterations of cells of the innate immune system are involved in the increased susceptibility of elderly individuals to infectious diseases. In particular, alterations in the number, phenotype, and functions of natural killer (NK) cells have been shown in the elderly $[8,12]$.

\section{NK Cell Subsets}

NK cells are bone marrow-derived lymphocytes that participate in the early defense against intracellular pathogens and tumor cells. They are cytotoxic non-T lymphocytes that do not rearrange the genes encoding the $\mathrm{T}$ cell antigen receptor and characterized by the expression of CD56 and/or CD16 [13]. NK cells are part of innate immunity, acting within hours of infection in contrast to CD8 T cells that require several days to proliferate and differentiate to cytolytic effector T cells. Peripheral blood NK cells represent $10-15 \%$ of all lymphocytes. Although NK cells have been considered for many years as being a simple, homogenous, and unspecific population in comparison with $\mathrm{T}$ or B cells of adaptive immunity, different subsets have been defined according to the expression of NK markers and their capacity to kill or produce cytokines. Human NK cells are classically divided into 2 functional subsets based on their cell surface density of CD56, i.e. CD56 ${ }^{\text {bright }}$ immunoregulatory cells and CD56 ${ }^{\mathrm{dim}}$ cytotoxic cells. Both subsets have been characterized extensively regarding their different functions, phenotype, and tissue localization. The CD56 $6^{\text {bright }} \mathrm{NK}$ cell subset has a distinctive role in the innate immune response as the primary source of NK cell-derived immunoregulatory cytokines [14-16] although CD56 ${ }^{\text {dim }} \mathrm{NK}$ cells can produce higher levels of cytokines and chemokines upon target cell recognition compared to CD56 $6^{\text {bright }}$ cells, as emphasized by Fauriat et al. [17]. CD56 ${ }^{\mathrm{dim}}$ and CD56 $6^{\text {bright }}$ subsets also differ in the expression of chemokine receptors that may contribute to cell trafficking [14, $18,19]$. In addition CD56 ${ }^{\text {dim }} \mathrm{NK}$ cells can be subdivided into functionally heterogeneous subsets ('educated' or 'licensed' vs. 'unlashed' or 'unlicensed' NK cells), based on the expression of other cell surface receptors, including inhibitory and activating KIR and NKG2A, which can interact with self-HLA class I ligands. Licensing of NK cells by self-MHC class I has been proposed as a mechanism for NK cell tolerance to self. This process results in 2 types of tolerant NK cells: (a) licensed NK cells that are functionally competent and whose effector responses are inhibited by self-MHC class I molecules through the same receptors that conferred licensing, and (b) unlicensed, functionally incompetent NK cells. This process was defined for mouse NK cells and several findings suggest that human NK cells also undergo this licensing process $[13,20-23]$. The acquisition of functional competence through 'licensing' by self-MHC molecules implies that effector-target interactions are governed by the integration of inhibitory and activating signals that determines whether the NK cell is finally activated, secretes cytokines, and lyses target cells [24].

In addition to this functional tuning by self-HLA class I ligands during NK cell education, it has been recently suggested that the NK cell number is maintained by a continuous differentiation process associated with the expression of CD57 that ends in NK cells with poor responsiveness to cytokine stimulation but high cytolytic capacity $[25,26]$. CD57+ NK cells show increased responsiveness to target cells and decreased responses to cytokines [25]; they are highly mature and display a mature phenotype, a higher cytotoxic capacity, a higher sensitivity to stimulation via CD16, a decreased responsiveness to cytokines, and a decreased capacity to proliferate compared to the CD57- counterparts [26], supporting the notion that a gradual shift in functionality occurs during differentiation from $\mathrm{CD} 56^{\text {bright }}$ via CD56 $6^{\mathrm{dim}} \mathrm{CD} 57-$ to CD56 ${ }^{\text {dim }}$ CD57+ NK cells (fig. 1).

This differentiation process is uncoupled from the functional tuning by self-HLA class I ligands during NK cell education, indicating that differentiation and education are parallel but uncoupled processes [25].

\section{Clinical Significance of NK Cells in the Elderly}

Several alterations have been described in NK cells with advancing age both in animals and in humans (table 1). The somehow contradictory results are likely due to the different criteria used for the inclusion of study subjects in the diverse studies of elderly humans. While some authors have used the strict SENIEUR criteria [27, 28 ] of very healthy elderly individuals or healthy cente- 
Table 1. Effect of aging on the NK cell compartment

\begin{tabular}{|c|c|}
\hline Parameter & Aging \\
\hline $\begin{array}{l}\text { Number } \\
\text { Number/percentage of NK cells }{ }^{\text {a }} \\
\text { CD56 } 6^{\text {bright }} \text { subset } \\
\text { CD } 56^{\text {dim }} \text { subset } \\
\text { In vivo proliferation and production rates }\end{array}$ & $\begin{array}{l}\text { preserved or increased } \\
\text { decreased } \\
\text { preserved or increased } \\
\text { decreased }\end{array}$ \\
\hline $\begin{array}{l}\text { Function } \\
\text { Natural cytotoxicity } \\
\text { ADCC } \\
\text { Proliferation } \\
\text { Response to cytokines } \\
\text { Cytokine and chemokine production } \\
\text { Intracellular signaling }\end{array}$ & $\begin{array}{l}\text { decreased or preserved } \\
\text { maintained } \\
\text { decreased } \\
\text { decreased or preserved } \\
\text { decreased } \\
\text { decreased }\end{array}$ \\
\hline $\begin{array}{l}\text { Phenotype } \\
\text { CD57 expression on CD56 } 6^{\mathrm{dim}} \text { cells } \\
\text { CD94/NKG2A expression } \\
\text { KIR expression } \\
\text { Perforin content }\end{array}$ & $\begin{array}{l}\text { increased } \\
\text { decreased } \\
\text { increased } \\
\text { decreased or preserved }\end{array}$ \\
\hline
\end{tabular}

${ }^{a}$ A decreased frequency is associated with an increased risk of infection, inflammation, or death.

narians, other authors have studied unselected populations of elderly people, analyzing the association of NK cell alterations with diseases or even with the risk of death. The studies using very healthy elderly people and centenarians show that the overall NK cell number tends to increase with age and that NK cytotoxicity is not significantly affected [29-35].

However, studies of unselected elderly populations have shown that the decreased NK cell function in old individuals is associated with an increased incidence of infectious diseases and death due to infection in elderly humans $[36,37]$, and elderly people (aged $>85$ years) with low numbers of NK cells have been reported to have an increased mortality risk in the first 2 years of follow-up compared to those with high NK cell numbers [38]. It has also been reported that decreased NK cell activity in the elderly is also associated with an increased frequency of disorders such as atherosclerosis [39] and that a preserved NK function is related to a better health status and a lower incidence of respiratory tract infections in elderly individuals and to a better response to influenza vaccination [40]. Additional evidence supporting the significance of NK cells in healthy aging comes from studies in nonagenarians and centenarians who, in general, have well preserved numbers and func-

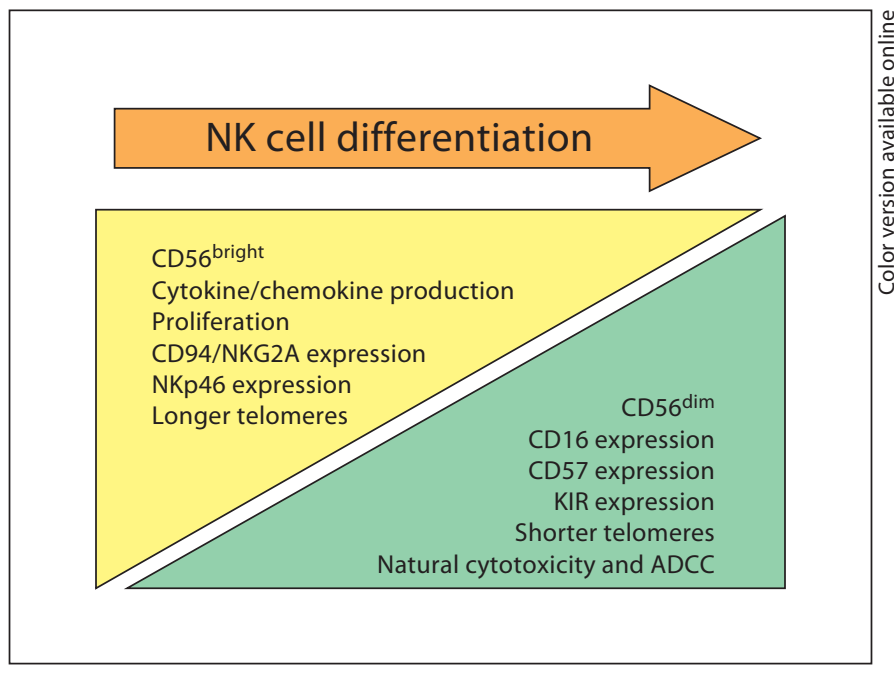

Fig. 1. Lineal model of the differentiation of peripheral blood NK cells. CD56 $6^{\text {bright }} \mathrm{NK}$ cells are more immature NK cells and the precursors of CD56 $6^{\mathrm{dim}}$ cells. Subsequent differentiation leads to phenotypic and functional changes associated with the acquisition of CD57. Aging is associated with a shift of these subsets with a reduction of CD56 $6^{\text {bright }}$ and expansion of CD56 $6^{\text {dim }} \mathrm{CD} 57+\mathrm{NK}$ cells.

tions of NK cells [35, 41, 42]; this is also associated with a better ability to maintain an autonomous life style, higher serum vitamin D levels, a well-nourished status, a balanced basal metabolism, and higher concentrations of micronutrients $[11,43,44]$. Together, these results support the fact that preserved NK cytotoxicity can be considered a marker of healthy aging, whereas low NK cytotoxicity is a predictor of increased morbidity and mortality due to infections.

It has also been shown that aging has an impact on NK cell kinetics [45]. These cells are in a state of dynamic homeostasis consistent with a model of postmitotic maturation preceding circulation and with a turnover time in blood of about 2 weeks. NK cells from healthy elderly subjects have proliferation and production rates which are significantly lower than those of NK cells from young healthy individuals [45], indicating that although NK cell numbers are well preserved in healthy aging there is a reduction in total NK cell production rates of $50 \%$ and suggesting an increased proportion of long-lived NK cells in the elderly subjects. This may be related to the increased proportion of $\mathrm{CD} 56^{\mathrm{dim}}$ cells, as previously reported in elderly subjects [29]. Furthermore, the increased expression of CD57 observed in NK cells from elderly donors $[29,32]$ also supports the ac- 
cumulation of terminally differentiated NK cells in the elderly subjects. The decreased proliferation and production rates of NK cells in the elderly can be associated with the telomere shortening observed in the elderly. Thus it has been demonstrated that NK lymphocytes show an age-associated loss of telomeres together with an age-associated reduction of telomerase activity that is evident in individuals over 80 years of age, in particular in the oldest individuals and in those with increased NK cell numbers $[46,47]$.

\section{Effect of Aging on NK Cell Subsets}

As discussed above, the NK cell frequency and absolute value tend to increase in healthy aging. However, a redistribution of $\mathrm{NK}$ cell subsets is also found in the elderly with a profound decrease of CD56 ${ }^{\text {bright }} \mathrm{NK}$ cells and a concomitant expansion of the CD56 ${ }^{\mathrm{dim}}$ subset $[29,30$, 32], suggesting that the increase in NK cell frequency with age results from expansion of the mature CD56 dim subset rather than of the immature CD56 ${ }^{\text {bright }} \mathrm{NK}$ subset. Furthermore, the expression of CD57 is increased on CD56 ${ }^{\text {dim }}$ NK cells from elderly donors. CD57 (HNK-1 epitope, sialyl-Lewis $\mathrm{X}$ ) is a sulfated trisaccharide preferentially added to $\mathrm{N}$-glycans of neural cell adhesion molecules, which is expressed on CD56 ${ }^{\mathrm{dim}} \mathrm{NK}$ cells and on CD28-CD8+ T cells $[48,49]$. It has recently been shown that $\mathrm{CD} 57+\mathrm{CD} 56^{\mathrm{dim}}$ cells represent a highly differentiated subset of NK cells. Thus, a continuous differentiation process of NK cells associated with the expression of CD57 that ends in cells with poor responsiveness to cytokine stimulation and retained cytolytic capacity has been proposed. CD57+ NK cells show an increased responsiveness to target cells and decreased responses to cytokines; this supports the notion that a gradual shift in functionality occurs during differentiation from CD56 $6^{\text {bright }}$ via CD57-CD56 ${ }^{\text {dim }}$ to CD57+ CD56 ${ }^{\text {dim }} \mathrm{NK}$ cells [25]. Transcriptional, phenotypic, and functional differences between CD57+ and CD57- NK cells also support the notion that CD57+ NK cells are highly mature and might be terminally differentiated, displaying a mature phenotype, a higher cytotoxic capacity, a higher sensitivity to stimulation via CD16, a decreased responsiveness to cytokines, and a decreased capacity to proliferate compared to the CD57- counterparts [26]. Thus the decline in $\mathrm{CD} 56^{\text {bright }} \mathrm{NK}$ cells and the increase in the CD56 ${ }^{\mathrm{dim}} \mathrm{CD} 57+$ subset support the notion that the population of NK cells suffers a process of remodeling with a reduction in the output of more immature CD56 $6^{\text {bright }}$ cells and an accumulation of highly differentiated CD56 ${ }^{\mathrm{dim}} \mathrm{CD} 57+\mathrm{NK}$ cells (fig. 1). This possibility can explain many of the phenotypic and functional features of NK cells in the elderly such as the altered expression of some NK receptors, decreased proliferative response to cytokines, or preservation of the CD16-mediated cytotoxic capacity.

This remodeling of NK cell subsets can also contribute to the dysregulation of other cells of the adaptive and innate immune system since CD56 bright cells are critical to the cytokine response of these cells; they can play an important role in the activation of dendritic cells (DCs) and interact with monocytes promoting inflammation $[14,19]$.

\section{Effect of Aging on the Expression and Function of NK Cell Receptors}

CD16 is the low-affinity IgG Fc receptor (Fc $\gamma$ RIII-A). It is expressed on NK cells and its cross-linking by antibody-coated target cells triggers the so-called antibodydependent cell cytotoxicity. CD16 associates with immunoreceptor tyrosine-based activation motif (ITAM)-containing chain (CD $3 \xi$ or FceRI $\gamma$ ) complexes. Signaling via CD16 activates the PI-3-kinase pathway and results in the production of cytokines, including IFN- $\gamma$, GM-CSF, and several chemokines, and causes degranulation of NK cells [50]. Neither CD16 expression nor CD16 function is affected by aging $[11,32,39,51-53]$, although it is of interest to note that cord blood and infant NK cells display very low CD16-dependent cytotoxicity [32].

Although the overall NK cell cytotoxicity is not significantly affected in very healthy elderly donors, it has been demonstrated that there is a decreased cytotoxicity of K562 target cells per NK cell and that the maintenance of the overall NK cell activity is probably due to the increase in NK cells $[32,44,53,54]$. The decreased per-cell NK cytotoxicity against the classic target cell line K562 suggests that the expression and/or functionality of other NK-activating receptors are likely to be defective in the elderly.

Little is known about the effects of aging on the expression and function of NK receptors other than CD16, and discrepant results have been reported in this context. While it was reported that the expression of HLA-specific killer immunoglobulin-like receptors (KIR) is not significantly affected in NK cells from elderly compared to young donors [44], another study showed an age-related increase in KIR expression and a reciprocal decrease in 
CD94/NKG2A expression [51]. A decreased expression of CD94 and of the coinhibitory receptor KLRG-1 on NK cells from old donors has been shown [55]. KLRG-1 has been postulated to be a marker of senescence in antigenexperienced $\mathrm{T}$ cells, although very little is known of its function in NK cells. In a recent study [32], no significant differences in KIR or CD94/NKG2A expression were observed between healthy adults and elderly donors, probably due to the high variability of the results and the broad age ranges considered. In that work [32], a group of cord blood samples was included and, interestingly, it was observed that cord blood NK cells displayed phenotypic features such as the lack of expression of CD57 and LIR1/ILT-2 or the low expression of KIR and high expression of NKG2A that could be linked to NK cell immaturity. Nevertheless, they express perforin [56] and produce high levels of IFN- $\gamma$ upon stimulation [32]. NK cells from cord blood have a low cytolytic capacity [32], but their cytolytic activity in infants is comparable to adult NK cytotoxicity [56].

In relation to the effect of aging on the expression of other NK receptors involved in NK cell cytotoxicity, a decreased expression of the activating receptor NKp30 has been shown in NK cells from elderly donors $[32,57,58]$. NKp30 also plays an important regulatory role mediating the cross talk between NK and DCs via the recognition of an unknown ligand expressed on DCs. The engagement of the NKp30 receptor can lead either to a direct killing of DCs by NK cells or to the secretion of IFN- $\gamma$ and TNF- $\alpha$ and the subsequent maturation of DCs. Therefore, NK-activated DCs loaded with tumor or virally derived antigen have an increased capacity to prime $\mathrm{T}$ cells. In return, activated DCs release Th1 cytokines that further enhance NK activation $[59,60]$. The decreased expression of NKp30 on NK cells from elderly individuals should also affect the interaction between these cells leading to a decreased capacity to collaborate in the initiation of the adaptive immune response against virus-infected or tumor cells.

\section{Effect of Aging on NK Cell Response to Cytokines}

Cytokine activation of NK cells results in proliferation, enhanced cytotoxicity, and the synthesis and release of cytokines and chemokines. While IL-2-induced NK cell proliferation is decreased in old donors [29], the enhancement of the cytotoxic activity of NK cells in response to IL-2, IL-12, or IFN- $\alpha$ and IFN- $\gamma$ is well preserved in the healthy elderly $[32,61-63]$. The production of IFN- $\gamma$ by NK cells after activation is also maintained in the elderly [32], with a increased production of IFN- $\gamma$ by $\mathrm{CD} 56^{\text {bright }}$ cells, potentially representing a compensatory augmentation of cytokine production to maintain the important immunoregulatory role of these cells in older individuals [55]. However, a marked early decrease in IFN- $\gamma$ secretion in response to IL-2, which can be overcome by increasing the incubation time, has also been shown [63]. The production of chemokines by NK cells is decreased in old subjects in response to IL-2 or IL-12 [6466]. Considering that $\mathrm{CD} 56^{\mathrm{dim}} \mathrm{NK}$ cells can produce high amounts of IFN- $\gamma$, and whereas chemokines are mainly produced by $\mathrm{CD} 56^{\text {bright }} \mathrm{NK}$ cells, the decrease in this subset in the elderly can explain their decreased production by NK cells associated with aging. Because of the costimulatory role of chemokines in NK responses, the decreased production of chemokines can be involved in the defective functional activity of NK cells from old subjects.

\section{Concluding Remarks}

NK cells are cytotoxic lymphocytes involved in the early defense against virus-infected and tumor cells. Besides their cytotoxic capacity, NK cells also regulate the immune response by producing cytokines and chemokines that directly participate in the elimination of pathogens or activate other cellular components of immunity. The NK cell frequency and absolute value tend to increase with age. In very healthy elderly, including centenarians, NK cell numbers and functions are well preserved, whereas decreased NK cell activity is associated with an increased incidence of infectious and inflammatory diseases. Several alterations have been described in human NK cells with advancing age, thus contributing to age-associated deterioration of the immune response. The results summarized in this work support the notion that aging leads to a redistribution of NK cell subsets with a decrease in CD56 $6^{\text {bright }}$ cells and an expansion of the CD56 ${ }^{\mathrm{dim}}$ subset, in particular highly differentiated CD56 ${ }^{\mathrm{dim}} \mathrm{CD} 57+\mathrm{NK}$ cells. Age-associated NK cell remodeling can explain many of the phenotypic and functional changes in NK cells associated with healthy aging.

Further studies on the effect of aging on all NK cell subsets and on the expression and function of activating and inhibitory receptors, as well as a more profound study of the molecular mechanisms involved in these processes, are required to better understand age-associ- 
ated NK cell alterations. Considering the increasing advances in the understanding of the mechanisms involved in NK cell interactions not only with tumor- and virusinfected target cells but also with other cells of the immune system, it is of high interest to analyze the contribution of NK cell aging to the process of immunosenescence.

\section{Acknowledgements}

This work has been supported by the Ministerio de Sanidad, Junta de Andalucía (FIS09/00723 and JA0292/07 to R.S.), the Ministerio de Ciencia e Innovacion and Junta de Extremadura (SAF2009-09711, GRU09156, and GRU10104 to R.T.), and the Spanish Network for Research in Infectious Disease (REIPI RD06/0008) cofinanced by the European Regional Development Fund (FEDER).

\section{References}

1 Brunner S, Herndler-Brandstetter D, Weinberger B, Grubeck-Loebenstein B: Persistent viral infections and immune aging. Ageing Res Rev 2010, E-pub ahead of print.

- 2 Grubeck-Loebenstein B, Della BS, Iorio AM, Michel JP, Pawelec G, Solana R: Immunosenescence and vaccine failure in the elderly. Aging Clin Exp Res 2009;21:201-209.

-3 Pawelec G, Derhovanessian E, Larbi A: Immunosenescence and cancer. Crit Rev Oncol Hematol 2010;75:165-172.

4 Fulop T, Kotb R, Fortin CF, Pawelec G, de Angelis F, Larbi A: Potential role of immunosenescence in cancer development. Ann NY Acad Sci 2010;1197:158-165.

5 Vasto S, Candore G, Balistreri CR, Caruso M, Colonna-Romano G, Grimaldi MP, Listi F, Nuzzo D, Lio D, Caruso C: Inflammatory networks in ageing, age-related diseases and longevity. Mech Ageing Dev 2007;128:83-91.

- 6 Wick G, Jansen-Durr P, Berger P, Blasko I, Grubeck-Loebenstein B: Diseases of aging. Vaccine 2000;18:1567-1583.

7 Larbi A, Franceschi C, Mazzatti D, Solana R, Wikby A, Pawelec G: Aging of the immune system as a prognostic factor for human longevity. Physiology (Bethesda) 2008;23:6474.

-8 DelaRosa O, Pawelec G, Peralbo E, Wikby A, Mariani E, Mocchegiani E, Tarazona R, Solana R: Immunological biomarkers of ageing in man: changes in both innate and adaptive immunity are associated with health and longevity. Biogerontology 2006;7:471-481.

\$9 Pawelec G, Barnett Y, Forsey R, Frasca D, Globerson A, McLeod J, Caruso C, Franceschi C, Fulop T, Gupta S, Mariani E, Mocchegiani E, Solana R: T cells and aging, January 2002 update. Front Biosci 2002; 7:d1056d1183.

10 Linton PJ, Dorshkind K: Age-related changes in lymphocyte development and function. Nat Immunol 2004;5:133-139.

- 11 Pawelec G, Solana R, Remarque E, Mariani E: Impact of aging on innate immunity. J Leukoc Biol 1998;64:703-712.

-12 Solana R, Pawelec G, Tarazona R: Aging and innate immunity. Immunity 2006;24:491494
13 Parham P: Taking license with natural killer cell maturation and repertoire development. Immunol Rev 2006;214:155-160.

14 Cooper MA, Fehniger TA, Caligiuri MA The biology of human natural killer-cell subsets. Trends Immunol 2001;22:633-640.

15 Farag SS, VanDeusen JB, Fehniger TA, Caligiuri MA: Biology and clinical impact of human natural killer cells. Int J Hematol 2003;78:7-17.

16 Wendt K, Wilk E, Buyny S, Buer J, Schmidt $\mathrm{RE}$, Jacobs R: Gene and protein characteristics reflect functional diversity of CD56dim and CD56bright NK cells. J Leukoc Biol 2006;80:1529-1541.

17 Fauriat C, Long EO, Ljunggren HG, Bryceson YT: Regulation of human NK-cell cytokine and chemokine production by target cell recognition. Blood 2010;115:2167-2176.

18 Berahovich RD, Lai NL, Wei Z, Lanier LL, Schall TJ: Evidence for NK cell subsets based on chemokine receptor expression. J Immunol 2006; 177:7833-7840.

19 Fehniger TA, Cooper MA, Nuovo GJ, Cella M, Facchetti F, Colonna M, Caligiuri MA: CD56bright natural killer cells are present in human lymph nodes and are activated by $\mathrm{T}$ cell-derived IL-2: a potential new link between adaptive and innate immunity. Blood 2003;101:3052-3057.

20 Yokoyama WM, Kim S: Licensing of natural killer cells by self-major histocompatibility complex class I. Immunol Rev 2006;214:143154.

21 Raulet DH: Missing self recognition and self tolerance of natural killer (NK) cells. Semin Immunol 2006;18:145-150.

22 Kim S, Poursine-Laurent J, Truscott SM, Lybarger L, Song YJ, Yang L, French AR, Sunwoo JB, Lemieux S, Hansen TH, Yokoyama WM: Licensing of natural killer cells by host major histocompatibility complex class I molecules. Nature 2005;436:709-713.

23 Raulet DH, Vance RE: Self-tolerance of natural killer cells. Nat Rev Immunol 2006;6: 520-531.

24 Gasser S, Raulet DH: Activation and self-tolerance of natural killer cells. Immunol Rev 2006;214:130-142.
25 Bjorkstrom NK, Riese P, Heuts F, Andersson $\mathrm{S}$, Fauriat C, Ivarsson MA, Bjorklund AT, Flodstrom-Tullberg M, Michaelsson J, Rottenberg ME, Guzman CA, Ljunggren HG, Malmberg KJ: Expression patterns of NKG2A, KIR, and CD57 define a process of CD56dim NK cell differentiation uncoupled from NK cell education. Blood 2010;116: 3853-3864.

26 Lopez-Verges S, Milush JM, Pandey S, York VA, Rakawa-Hoyt J, Pircher H, Norris PJ, Nixon DF, Lanier LL: CD57 defines a functionally distinct population of mature $\mathrm{NK}$ cells in the human CD56dimCD16+ NK cell subset. Blood 2010;116:3865-3874.

27 Ligthart GH: The SENIEUR protocol after 16 years: the next step is to study the interaction of ageing and disease. Mech Ageing Dev 2001;122:136-140.

28 Ligthart GJ, Corberand JX, Geertzen HG Meinders AE, Knook DL, Hijmans W: Necessity of the assessment of health status in human immunogerontological studies: evaluation of the SENIEUR protocol. Mech Ageing Dev 1990;55:89-105.

29 Borrego F, Alonso MC, Galiani MD, Carracedo J, Ramirez R, Ostos B, Pena J, Solana R: NK phenotypic markers and IL2 response in NK cells from elderly people. Exp Gerontol 1999;34:253-265.

30 Chidrawar SM, Khan N, Chan YL, Nayak L, Moss PA: Ageing is associated with a decline in peripheral blood CD56bright NK cells. Immun Ageing 2006;3:10.

31 Facchini A, Mariani E, Mariani AR, Papa S, Vitale M, Manzoli FA: Increased number of circulating Leu 11+ (CD 16) large granular lymphocytes and decreased NK activity during human ageing. Clin Exp Immunol 1987; 68:340-347.

32 Le Garff-Tavernier M, Beziat V, Decocq J, Siguret V, Gandjbakhch F, Pautas E, Debre P, Merle-Beral H, Vieillard V: Human NK cells display major phenotypic and functional changes over the life span. Aging Cell 2010; 9:527-535. 
-33 Ligthart GJ, Schuit HR, Hijmans W: Natural killer cell function is not diminished in the healthy aged and is proportional to the number of NK cells in the peripheral blood. Immunology 1989;68:396-402.

- 34 Mariani E, Roda P, Mariani AR, Vitale M, Degrassi A, Papa S, Facchini A: Age-associated changes in CD8+ and CD16+ cell reactivity: clonal analysis. Clin Exp Immunol 1990;81:479-484.

- 35 Sansoni P, Cossarizza A, Brianti V, Fagnoni F, Snelli G, Monti D, Marcato A, Passeri G, Ortolani C, Forti E: Lymphocyte subsets and natural killer cell activity in healthy old people and centenarians. Blood 1993;82:27672773.

- 36 Ogata K, Yokose N, Tamura H, An E, Nakamura K, Dan K, Nomura T: Natural killer cells in the late decades of human life. Clin Immunol Immunopathol 1997;84:269-275.

37 Ogata K, An E, Shioi Y, Nakamura K, Luo S, Yokose N, Minami S, Dan K: Association between natural killer cell activity and infection in immunologically normal elderly people. Clin Exp Immunol 2001;124:392-397.

-38 Remarque E, Pawelec G: T cell immunosenescence and its clinical relevance in man. Rev Clin Gerontol 1998;8:5-14.

- 39 Bruunsgaard H, Pedersen AN, Schroll M, Skinhoj P, Pedersen BK: Decreased natural killer cell activity is associated with atherosclerosis in elderly humans. Exp Gerontol 2001;37:127-136.

-40 Mysliwska J, Trzonkowski P, Szmit E, Brydak LB, Machala M, Mysliwski A: Immunomodulating effect of influenza vaccination in the elderly differing in health status. Exp Gerontol 2004;39:1447-1458.

-41 Franceschi C, Monti D, Sansoni P, Cossarizza A: The immunology of exceptional individuals: the lesson of centenarians. Immunol Today 1995;16:12-16.

42 Sansoni P, Brianti V, Fagnoni F, Snelli G, Marcato A, Passeri G, Monti D, Cossarizza A, Franceschi C: NK cell activity and T-lymphocyte proliferation in healthy centenarians. Ann NY Acad Sci 1992;663:505-507.

-43 Ravaglia G, Forti P, Maioli F, Bastagli L, Facchini A, Mariani E, Savarino L, Sassi S, Cucinotta D, Lenaz G: Effect of micronutrient status on natural killer cell immune function in healthy free-living subjects aged $\geq 90 \mathrm{y}$. Am J Clin Nutr 2000;71:590-598.

-44 Mariani E, Monaco MC, Cattini L, Sinoppi M, Facchini A: Distribution and lytic activity of NK cell subsets in the elderly. Mech Ageing Dev 1994;76:177-187.
45 Zhang Y, Wallace DL, de Lara CM, Ghattas $\mathrm{H}$, Asquith B, Worth A, Griffin GE, Taylor GP, Tough DF, Beverley PC, Macallan DC: In vivo kinetics of human natural killer cells: the effects of ageing and acute and chronic viral infection. Immunology 2007;121:258265.

46 Mariani E, Meneghetti A, Formentini I, Neri S, Cattini L, Ravaglia G, Forti P, Facchini A: Different rates of telomere shortening and telomerase activity reduction in CD8 T and CD16 NK lymphocytes with ageing. Exp Gerontol 2003;38:653-659.

47 Mariani E, Meneghetti A, Formentini I, Neri S, Cattini L, Ravaglia G, Forti P, Facchini A: Telomere length and telomerase activity: effect of ageing on human NK cells. Mech Ageing Dev 2003; 124:403-408.

48 Tarazona R, DelaRosa O, Alonso C, Ostos B, Espejo J, Pena J, Solana R: Increased expression of NK cell markers on T lymphocytes in aging and chronic activation of the immune system reflects the accumulation of effector/ senescent T cells. Mech Ageing Dev 2000; 121:77-88.

49 Brenchley JM, Karandikar NJ, Betts MR, Ambrozak DR, Hill BJ, Crotty LE, Casazza JP, Kuruppu J, Migueles SA, Connors M, Roederer M, Douek DC, Koup RA: Expression of CD57 defines replicative senescence and antigen-induced apoptotic death of CD8+ T cells. Blood 2003;101:2711-2720.

50 Lanier LL: Natural killer cell receptor signaling. Curr Opin Immunol 2003;15:308-314.

51 Lutz CT, Moore MB, Bradley S, Shelton BJ, Lutgendorf SK: Reciprocal age related change in natural killer cell receptors for MHC class I. Mech Ageing Dev 2005;126: 722-731.

52 Solana R, Alonso MC, Pena J: Natural killer cells in healthy aging. Exp Gerontol 1999;34: 435-443.

53 Solana R, Mariani E: NK and NK/T cells in human senescence. Vaccine 2000;18:16131620.

54 Mariani E, Ravaglia G, Meneghetti A, Tarozzi A, Forti P, Maioli F, Boschi F, Facchini A: Natural immunity and bone and muscle remodelling hormones in the elderly. Mech Ageing Dev 1998;102:279-292.

55 Hayhoe RP, Henson SM, Akbar AN, Palmer DB: Variation of human natural killer cell phenotypes with age: identification of a unique KLRG1-negative subset. Hum Immunol 2010;71:676-681.
56 Bryceson YT, Rudd E, Zheng C, Edner J, Ma D, Wood SM, Bechensteen AG, Boelens JJ, Celkan T, Farah RA, Hultenby K, Winiarski J, Roche PA, Nordenskjold M, Henter JI, Long EO, Ljunggren HG: Defective cytotoxic lymphocyte degranulation in syntaxin-11 deficient familial hemophagocytic lymphohistiocytosis 4 (FHL4) patients. Blood 2007; 110:1906-1915.

57 Tarazona R, Gayoso I, Alonso C, Pita-Lopez ML, Peralbo E, Casado JG, Sanchez-Correa B, Morgado S, Solana R: NK cells in human ageing; in Fulop T, Franceschi C, Hirokawa K, Pawelec G (eds): Handbook on Immunosenescence. New York, Springer, 2009, pp 533-546.

58 Sanchez-Correa B, Gayoso I, Bergua JM, Casado JG, Morgado S, Solana R, Tarazona R: Decreased expression of DNAM-1 on NK cells from acute myeloid leukemia patients. Immunol Cell Biol 2011, E-pub ahead of print.

59 Arnon TI, Achdout H, Levi O, Markel G, Saleh N, Katz G, Gazit R, Gonen-Gross T, Hanna J, Nahari E, Porgador A, Honigman A, Plachter B, Mevorach D, Wolf DG, Mandelboim O: Inhibition of the NKp30 activating receptor by pp 65 of human cytomegalovirus. Nat Immunol 2005;6:515-523.

60 Arnon TI, Markel G, Mandelboim O: Tumor and viral recognition by natural killer cells receptors. Semin Cancer Biol 2006;16:348358.

61 Kutza J, Murasko DM: Effects of aging on natural killer cell activity and activation by interleukin-2 and IFN-alpha. Cell Immunol 1994;155:195-204.

62 Kutza J, Murasko DM: Age-associated decline in IL-2 and IL-12 induction of LAK cell activity of human PBMC samples. Mech Ageing Dev 1996;90:209-222.

63 Murasko DM, Jiang J: Response of aged mice to primary virus infections. Immunol Rev 2005;205:285-296.

64 Mariani E, Pulsatelli L, Meneghetti A, Dolzani P, Mazzetti I, Neri S, Ravaglia G, Forti P, Facchini A: Different IL-8 production by $\mathrm{T}$ and NK lymphocytes in elderly subjects. Mech Ageing Dev 2001;122:1383-1395.

-65 Mariani E, Meneghetti A, Neri S, Ravaglia G, Forti P, Cattini L, Facchini A: Chemokine production by natural killer cells from nonagenarians. Eur J Immunol 2002;32:15241529.

66 Mariani E, Pulsatelli L, Neri S, Dolzani P, Meneghetti A, Silvestri T, Ravaglia G, Forti P, Cattini L, Facchini A: RANTES and MIPlalpha production by $\mathrm{T}$ lymphocytes, monocytes and NK cells from nonagenarian subjects. Exp Gerontol 2002;37:219-226. 